\title{
Fly Ash-Slag Binder in Construction Materials
}

\author{
Agnieszka Machowska* \\ Department of Hydro and Environmental Engineering, Poland
}

*Corresponding author: Agnieszka Machowska, Department of Hydro and Environmental Engineering, Warsaw, Poland

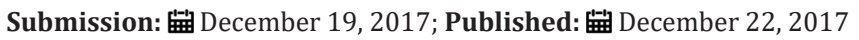

\section{Opinion}

Fulfilling the requirements of The Circular Economy policy established in European Union and necessity of limiting $\mathrm{CO}_{2}$ atmospheric emissions from the cement production process great emphasis is put on the utilisation of the wastes from coal combustion-by products from the power industry (slags and fly ashes). The cement production generates annual emissions of about $800 \mathrm{~kg} / 1 \mathrm{Mg}$ of clinker. Hence, the use of by-products instead of cement allows for a limiting of $\mathrm{CO}_{2}$ emissions. Moreover, economic reasons have also forced a search for alternative (non-clinker) binders which can be used in concrete technology. Fly ashes from pulverized coal combustion process have been successfully used in cement and concrete production for many years $[1,2]$. The ecological advantages of fluidized coal combustion are out of question, but the by-product obtained in these process-fly ash-exhibits specific properties, such as great specific surface of grains and high water demand, comparing to typical fly ash. These properties limit the possibilities of using fly ash from fluidized combustion in cement and concrete technology.

Ground granulated blast furnace slag (ggbfs) is a by-product of metallurgy industry and is a valuable binding material used for Portland slag cement production. It requires appropriate chemical activation to reveal hydraulic properties in time of curing and phase that share the characteristics of Portland cement [3]. Slag composites also present high water tightness and resistance to the impact of aggressive agents [4].

Slag can be activated by the addition of fly ash and chemical activators [5,6], but also by the addition of fluidized fly ash containing significant amounts of $\mathrm{CaO}$ and $\mathrm{SO}_{3}$ [7] and also of recommended mixes of this type of fly ash with slag [8]. Chemical activation of slags brings the risk of environment contamination and requires ensuring safety conditions of work.

The two by-products (ground granulated blast furnace slag and fly ash from circular fluidized bed combustion of brown coal-CFBC fly ash) can be used together in different construction materials applied in various structures. Although this type of fly ash is not approved to be used for cement and concrete production, the composition of slag and CFBC fly ash has been successfully used in hardening slurry-construction material of cut-off walls executed in flood protecting dikes [9]. The slurries made of different proportions of components (slag and fly ash) shown desired properties such as: compressive strength after 28 days of curing within the ranges of $0,5 \div 2,5 \mathrm{MPa}$ providing a proper work of cut-off wall in the ground and permeability coefficient after 28 days of curing within the ranges of $1,6 \cdot 10-7 \div 5,0 \cdot 10-10 \mathrm{~m} / \mathrm{s}$ providing appropriate water tightness of cut-off wall. The investigation into phase composition and microstructure revealed the appearance of phases typical for cement composites (hydrated calcium silicates, ettringite).

The fly ash-slag binder (with five proportions of components) was used to form pastes which were investigated into the early hydration process considering heat of hydration, soundness, initial and final setting time and early mechanical strength [10]. The research concerning the hydration products and properties of fly ash-slag pastes after 28 and 90 days of hydration [11] confirmed developing the mechanical strength and forming the solid microstructure of pastes with hydration products typical for cement composites. The results are promising and reveal suitable pozzolanic and hydraulic properties of mixtures and show the possibility of binder application in mass concrete considering the limited heat of hydration. The investigation towards the possibility of application fly ash-slag binder in concrete is being conducted. Further research of the non-clinker binder in pastes, mortars and concrete should be conducted to optimize the composition of mixes and to improve the properties of investigated materials.

\section{References}

1. Lutze D, Berg WV (2004) Handbook on fly ash in concrete by Verlag Bau+Technik GmbH, Dusseldorf, Germany.

2. Brandt M (2010) Utilization of fly ashes from circulating fluidal bed combustion in construction concrete. Pol Acad of Sci Com of Civil Eng, Warsaw, Poland.

3. Bakharev T, Sanjayan JG, Cheng YB (2003) Resistance of alkali-activated slag concrete to acid attack. Cem Concr Res 33: 1607-1611.

4. Bakharev T, Sanjayan JG, Cheng YB (2002) Sulfate attack on alkaliactivated slag concrete. Cem Concr Res 32: 211-216.

5. Bilim C, Atis CD (2012) Alkali activation of mortars containing different replacement levels of ggbfs. Constr Build Mater 28: 708-712. 
6. Grzymek DA, Małolepszy J, Brylicki W, Deja J (1990) Hydraulic-alkaline binder, Polish patent PL 162716.

7. Dung NT, Chang TP, Chen CT, Yang TR (2016) Cementitious properties and microstructure of an innovative slag eco-binder. Mater Struct 49(5): 2009-2024.

8. Nguyen HA, Chang TP, Shih JY, Chen CT, Nguyen TD (2016) Engineering properties and durability of high-strength self-compacting concrete with no-cement SFC binder. Constr Build Mater 106: 670-677.
9. Kledyński Z, Machowska A (2013) Hardening slurries with ground granulated blast furnace slag with fluidal fly ash from lignite combustion. Przem Chem 92(4): 490-497.

10. Machowska A, Kledyński Z, Wilińska I, Pacewska B (2017) Investigation of early hydration process and properties of fly ash-slag binders. Constr and Build Mat (paper in review process).

11. Kledyński Z, Machowska A, Pacewska B, Wilińska I (2017) Investigation of hydration products of fly ash-slag pastes. J Therm Anal Calorim 130: 351-365. 